\title{
The Use of Tissue Conditioner or Zinc Oxide and Eugenol Impression Paste in the Excision of Epulis Fissurata
}

\author{
by \\ Luis Augusto PASSERI, D.D.S.*, Ennes Macari de ABREU, D.D.S., D.Sc**, \\ Antonio Cesar Perri de CARVALHO, D.D.S., D.Sc.*** \\ and Sérgio Roberto Peres LINE, D.D.S.****
}

(Received 16 February 1987)

Key words: tissue conditioner, zinc oxide and eugenol impression paste, epulis fissurata, biocompatibility

\begin{abstract}
Either tissue conditioner or zinc oxide and eugenol impression paste were used to protect bloody surfaces in sixteen patients who had undergone excision of epulis fissurata. The patients were examined clinically at seven, fourteen and twenty-one days, and histologically at seven and fourteen days. The tissue conditioner was observed to show greater biocompatibility.
\end{abstract}

\section{Introduction}

The excision of epulis fissurata may lead to a reduction in the size of the vestibular sulcus due to tissue contraction during the wound healing process. There are various methods of inhibiting this contraction, including the use of the denture itself or of a surgical guide lined with temporary materials.

Zinc oxide and eugenol impression paste is frequently used for this purpose. However, in addition to its hard consistency, it contains approximately $12 \%$ eugenol $^{[1]}$, which tends to irritate the tissues ${ }^{[2,3,4]}$. The use of tissue conditioner would thus seem more recommendable. These materials retain their resilience for a period which varies from one week to one month ${ }^{[5]}$.

Such conditioners have been used in contact with bloody surfaces, as a substitute for the surgical periodontal pack $^{[6]}$, as a form of liner for immediate dentures $^{[7]}$ and as a lining material for surgical guides in pre-prosthetic surgery ${ }^{[8]}$.

TASSAROTTI and VALLARDI ${ }^{[7]}$ carried out a histological follow-up of the healing of supporting oral mucosa in patients that had received immediate dentures lined with conditioner. SATo et al. ${ }^{[9]}$ used histological and histochemical procedures to

* Assistant Professor, Cirurgia e Traumatologia Buco-Maxilo-Facial, Faculdade de Odontologia de Piracicaba-UNICAMP, São Paulo, Brasil

** Professor, Cirurgia e Traumatologia Buco-Maxilo-Facial, Faculdade de Odontologia de Piracicaba-UNICAMP, São Paulo, Brasil

*** Professor, Cirurgia e Traumatologia Buco-Maxilo-Facial, Faculdade de Odontologia do "Campus" de Araçatuba-UNESP, São Paulo, Brazil

**** Graduate, Patologia, Faculdade de Medicina Veterinária e Zootecnia-USP, São Paulo, Brasil 
observe the effect of tissue conditioner and dentures with an acrylic resin base on the healing of wounds in the palatal mucosa of dogs.

PASSERI and CARVALHO ${ }^{[4]}$, in a histological study of the healing of bloody areas in the palate and in surgical osseous cavities in the mandibles of rats, investigated the use of zinc oxide and eugenol impression paste and of conditioners, and found greater biocompatibility when the latter was employed.

Considering the scarcity of scientific literature in this field, as well as the results obtained in experimental animals, we performed a clinical and histological evaluation of patients undergoing excision of epulis fissurata.

\section{Materials and Methods}

Sixteen patients of both sexes, between 28 and 62 years of age (average 48 years), with epulis fissurata in the anterior region of the alveolar ridge, participated in the study. In all cases, surgery was performed using infiltration of local anesthesia and the specimen removed was submitted to biopsy. After the surgery, the denture itself or a surgical guide which had been prepared previously was inserted. In eight cases, zinc oxide and eugenol impression paste (Pasta Lysanda, Lab. Lysanda Ltda.) was used as a liner, while in the remaining eight cases tissue conditioner (Lynal, The L.D. Caulk Co.) was used. The material was replaced seven days after surgery and again seven days later.

Biopsies were performed on patients in both groups. Four in each group were biopsied seven days after surgery and the remainder at fourteen days. After antisepsis with uncolored tergentolate and terminal anesthesia relatively close to the affected area, a fragment of the wound border was removed, with a surface area of approximately $3 \times 5 \mathrm{~mm}$ and a depth corresponding to the periosteum. The specimens were sectioned and stained with hematoxylin and eosin for histological study.

The area was examined clinically at seven, fourteen and twenty-one days after surgery, and signs and symptoms were evaluated in terms of standardized criteria with regard to pain, odor, secondary hemorrhage, suppuration, peripheral inflammation and adherence of the material to the surgical wound, using a procedure similar to that adopted by LimA et al. ${ }^{[10]}$.

\section{Results}

\section{Clinical Observations}

With regard to pain, more complaints occurred among the patients who used zinc oxide and eugenol impression paste, pain being intense in some cases at seven days and, in two patients, persisting moderately at fourteen days. The only patient in the conditioner group to complain of moderate odor after seven days was observed to have inadequate oral hygiene. In addition, only one case of moderate secondary hemorrhage occurred at seven days in the zinc oxide and eugenol impression paste group. No case of suppuration was found.

\section{Histological Observations}

In all of the patients, the appearance of the lesions was compatible with epulis fissurata: mucosa covered with stratified and keratinized squamous epithelium, areas of acanthosis and dense fibrous protuberances into the connective tissue with 


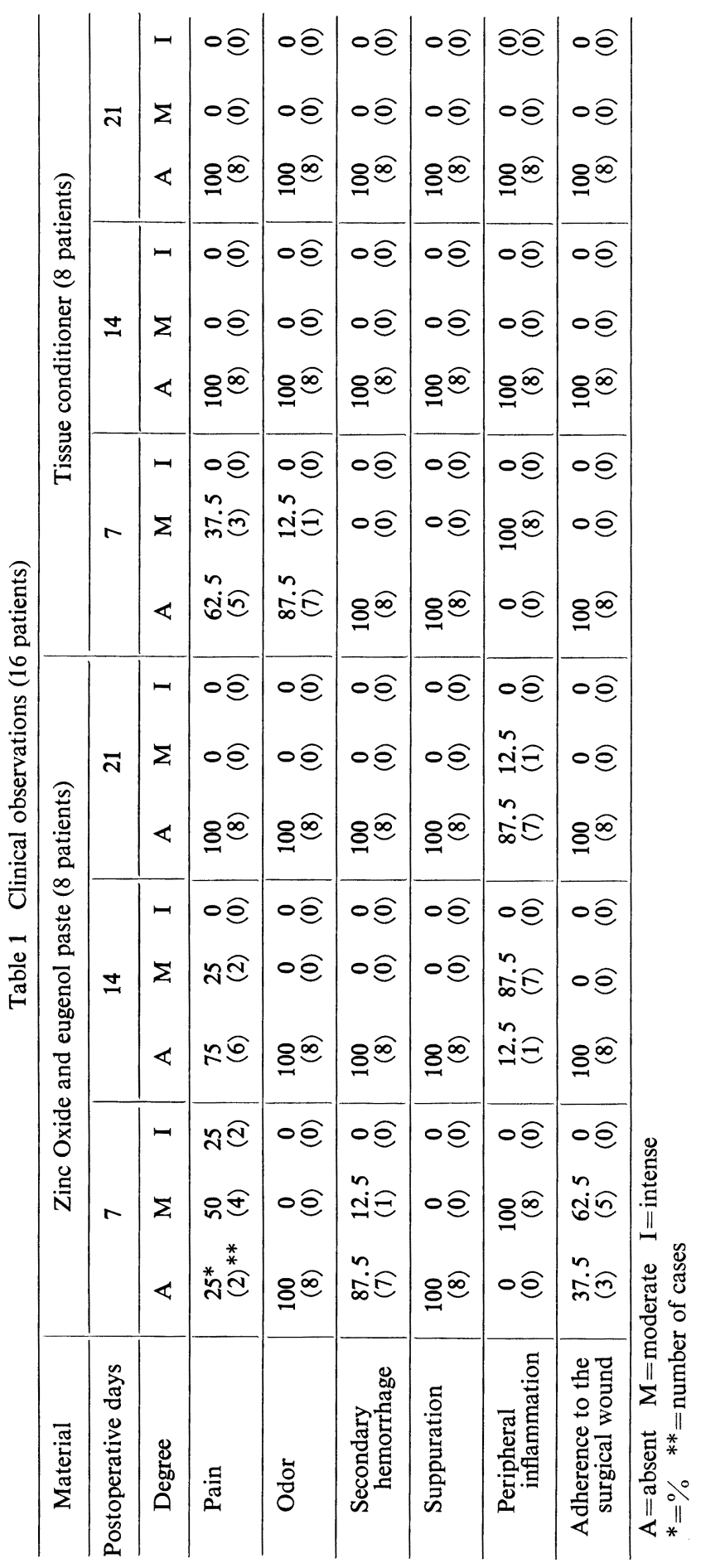


mature, well-oriented fibers, blood vessels and some areas of inflammatory cells, mostly mononuclear (Fig. 1).

At seven days after surgery, the surgical wounds were intensely infiltrated in the zinc oxide and eugenol impression paste group, but did not exhibit proliferation of the fibroblasts (Fig. 2). In the tissue conditioner group, hyaline substance covered

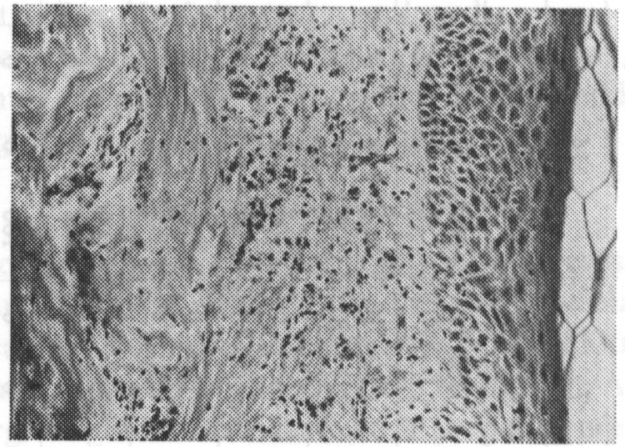

Fig. 1 Epulis fissurata (hematoxylin and eosin stain, original magnification $\times 180$ )

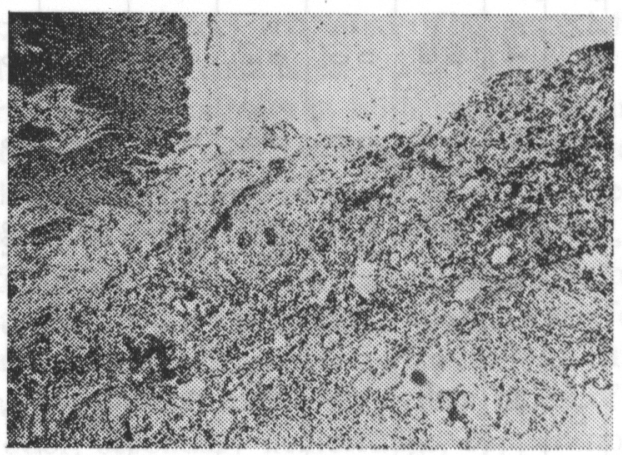

Fig. 2 Zinc oxide and eugenol impression paste -7 days (hematoxylin and eosin stain. original magnification $\times 75$ )

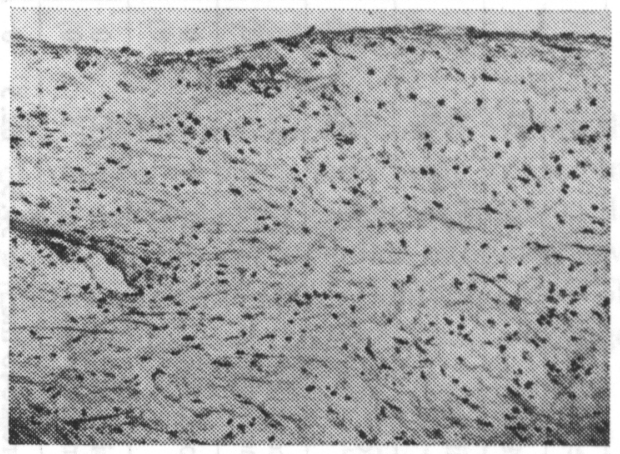

Fig. 3 Tissue conditioner -7 days (hematoxylin and eosin stain, original magnification $\times 180$ ) 


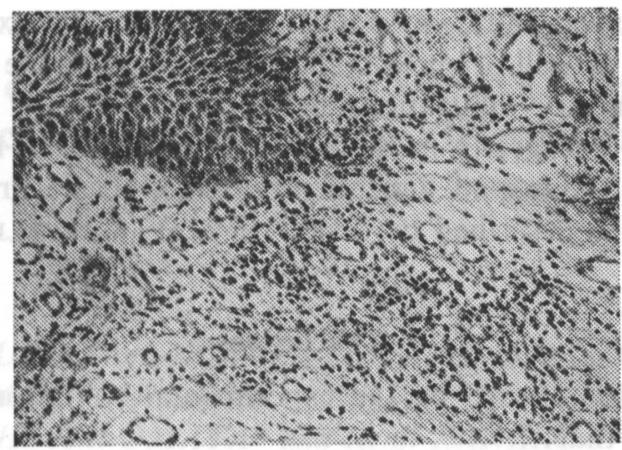

Fig. 4 Zinc oxide and eugenol impression paste-14 days (hematoxylin and eosin stain, original magnification $\times 180$ )

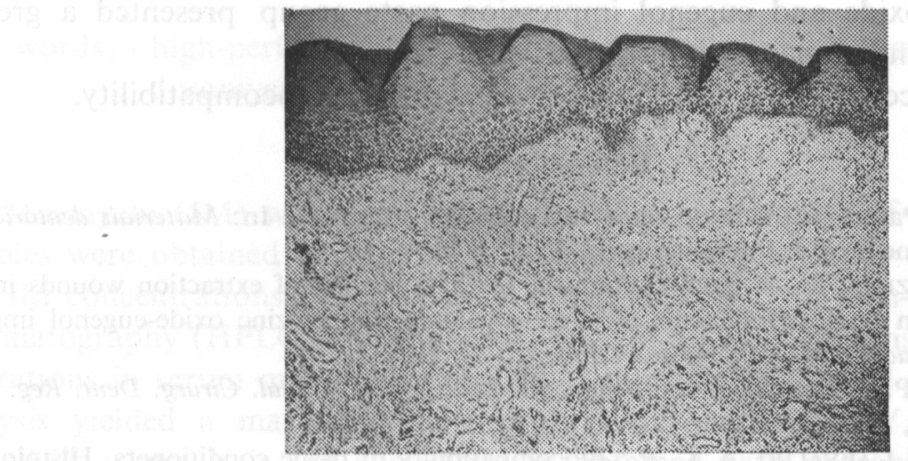

Fig. 5 Tissue conditioner-14 days (hematoxylin and eosin stain, original magnification $\times 75)$

the wound and collagen fibers were observed (Fig. 3). On the margins of the wounds, the epithelium presented signs of regeneration.

At fourteen days in the impression paste group, a large number of inflammatory cells were present (in comparison with the other group) and were invading the epithelium, which partially covered the wound, and which presented acanthosis. A large number of blood vessels were also present, and collagen fibers were observed (Fig. 4). In the conditioner group, the epithelium covered the area completely, exhibiting parakeratosis, slight acanthosis and few protuberances into the connective tissue, which showed intense proliferation of collagen fibers with some organization (Fig. 5).

\section{Discussion}

Clinically, slight differences were observed between the two groups, although patients who used tissue conditioner said they experienced a greater degree of comfort, probably due to the material's resiliency, as cited by MCGARTHY and MOSER ${ }^{[5]}$.

Discrepancies were greater, however, from a histological viewpoint. In the periods that were analyzed, the tissue conditioner group demonstrated greater biocompatibility, coinciding with results presented by TASSAROTTI and VALLARDI ${ }^{[7]}$, 
Sato et al. ${ }^{[9]}$, and Passeri and CARvalho ${ }^{[4]}$. This group also exhibited less acanthosis and greater numbers of well-oriented collagen fibers, while the paste group presented pronounced inflammatory infiltration. Better promotion of healing was also observed in the conditioner group in the period from seven to fourteen days as compared with the zinc oxide and eugenol impression paste group, where the paste acted as an irritant, as described by ABreu et al. ${ }^{[2]}$, CARVAlho ${ }^{[3]}$, and PASSERI and CARVAlHo ${ }^{[4]}$.

\section{Conclusions}

Within the limits imposed by the experimental conditions that have been described, we conclude that:

(a) the tissue conditioner group presented earlier organization of collagen fiber bundles;

(b) the zinc oxide and eugenol impression paste group presented a greater degree of inflammatory infiltration; and

(c) the tissue conditioner was shown to have greater biocompatibility.

\section{References}

[1] Phillips, R. W.: Pastas de óxido de zinco-eugenol para impressão. In: Materiais dentários de Skinner, Rio de Janeiro, Ed. Interamericana, 72-9, 1978

[2] Abreu, E. M., Vizioli, M. R. and Valdrighi, L.: The healing of extraction wounds in the presence of foreign bodies (fragments of silver amalgam and of zinc oxide-eugenol impression paste), Rev. Fac. Odont. S. José dos Campos, 3(2), 119-31, 1974

[3] Carvalho, A. C. P.: Observações sobre sulcoplastias, Rev. Ass. paul. Cirurg. Dent. Reg. Araçatuba, I(1), 18-23, 1980

[4] Passeri, L. A. and Carvalho, A. C. P.: Biocompatibility of tissue conditioners. Histological study in rats. J. Nihon Univ. Sch. Dent., 27(3), 167-73, 1985

[5] MCCarthy, J. A. and Moser, J. B.: Mechanical properties of tissue conditioners. Part I: The practical considerations, behavioral characteristics, and tensile properties, J. prosth. Dent., 40, 89-97, 1978

[6] Frisch, J., Levin, M. P. and Bhaskar, S. N.: The use of tissue conditioners in periodontics, J. Periodont., 39(6), 359-61, 1968

[7] Tassarotti, B. and Vallardi, E.: Quadro istologico di modificazioni mucose, inditte in soggetti dall'uso di protesi imediata con materiale di ricondizionamento, Rass. int. Stomat. prat., 20, 199-205, 1969

[8] Von Kramer, K. R.: Tissue conditioners, J. prosth. Dent., 25(3), 244-50, 1971

[9] Sato, T., Sasaki, H., TAKaki, Y., Yagi, T. and Tsuru, H.: The effect of tissue conditioner and resin base on wound healing of palatal mucosa in dog, J. Osaka Univ. dent. Sch., 17, 11931,1977

[10] Lima, A. C. O., Carvalho, A. C. P. and Martinelli, C.: The use of homogenous dura mater in the excision of epulis fissurata, Quint. int., 6, 625-33, 1982 